\title{
ARS Rangeland Research: Enhancing Economic and Environmental Sustainability
}

\author{
National research program meets future's challenges.
}

\author{
By ARS Information Staff
}

This year, the Agricultural Research Service (ARS) is celebrating its 50th anniversary as the US Department of Agriculture's chief scientific research agency. Since the agency's creation in 1953, research to solve problems associated with managing rangelands has been a part of ARS's primary mission.

Over the years, ARS has helped provide information to enhance livestock production, improve forages, sustain and restore rangelands, enhance wildlife habitat, and maintain soil, water, and air resources. Such research has helped transform range management from being chiefly an art to more of a science.

This special supplement provides a quick overview of what ARS has accomplished through the years to help rangeland managers, where ARS research is today, and where it may take us tomorrow.

\section{Edward Knipling}

Administrator

Agricultural Research Service

$\mathrm{R}$ angeland management is extremely complex, requiring the integration and consideration of a variety of factors, including soil erosion, biological diversity, rainfall patterns, biomass production, soil genesis, invasive weeds, and wildlife ecology. But its goal is often very straightforward and simple: information for producers on how they can achieve optimal livestock production while sustaining the land.

As the chief scientific research agency of the US Department of Agriculture (USDA), the Agricultural Research Service's (ARS's) job is to develop data about all factors of rangeland management, including production of livestock, to transform that data into an improved understanding of the rangeland environment, and to utilize that understanding as a coherent, sound scientific basis for decision making.
Customers for ARS's rangeland research include all those who are called on to make decisions about managing the land at all levels. This includes USDA's Forest Service and Natural Resources Conservation Service (NRCS); the Interior Department's Bureau of Land Management (BLM), Fish and Wildlife Service, Bureau of Indian Affairs, and National Park Service; and the US Environmental Protection Agency as well as many comparable state and local agencies. It also includes stakeholders, such as producer groups and organizations, individual ranchers, farmers, and private landowners, all of whom must make decisions about how to manage the land wisely.

The public is also an important ARS stakeholder. Rangelands are an essential environmental treasure of the country, and rangeland health is a long-term necessity that research helps support. 
Of course, there are competing uses of rangeland, and determining the right balance of these varied uses involves social decisions beyond the scope of ARS's mission. But such decisions have a better chance of working out well when there is a fact-based foundation and an understanding of how the physical world reacts to varying management actions.

ARS's research programs are guided and prioritized with the input of stakeholders through meetings, workshops, and individual communication. This ensures that ARS is addressing problems that are of the highest priority to all its stakeholders.

One of the exceptional points of ARS's research program is that it is national in scope, encompassing the many research needs and challenges of the major climatic and ecological regions that make up rangelands across the country. Rangeland research is located in 20 ARS laboratories, supported by about $\$ 23$ million per year in appropriated funds. It is the largest federal rangeland management research program.

Today, ARS takes a global approach to rangeland research, stressing interactions between a wide variety of factors.

"The common theme with our research is to seek ways to manage the health of rangelands by working with the ecology and balancing the needs and impacts of multiple uses of the lands," explained Evert K. Byington, ARS National Program Leader for Rangeland, Pasture, and Forages. "Our goal is to produce the information and tools that provide sound, science-based information that improves decision-making."

ARS rangelands research is basically divided into 5 major components: ecosystems and their sustainable management, plant resources and forage management, grazing management for livestock production and the environment, integrated management of weeds and pests, and decision support systems.

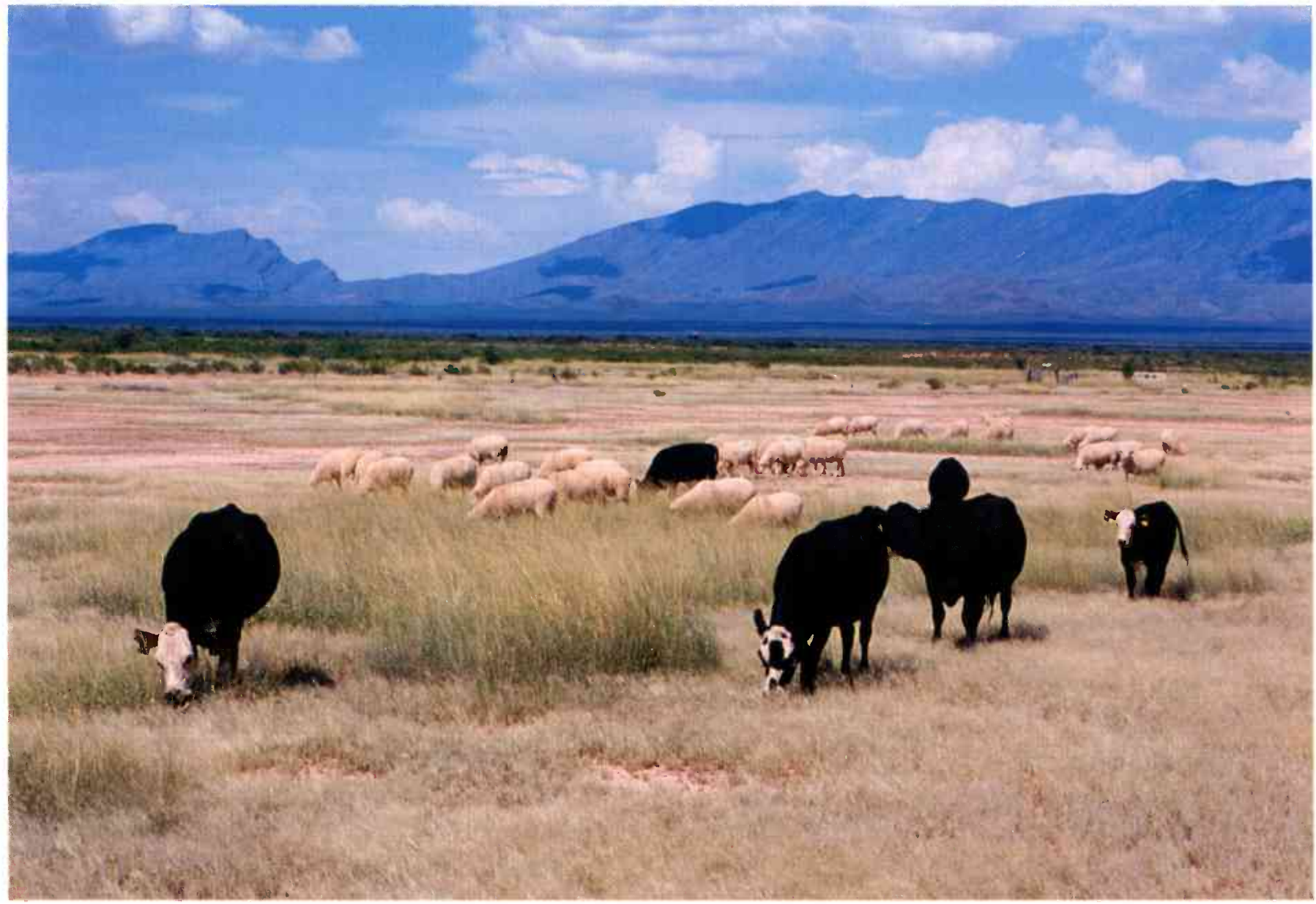

Cattle and sheep grazing together in a "flerd." The animals are bonded socially, so they remain together. 


\section{Arid Lands}

To really understand what is happening on rangeland, long-term benchmarks are needed. That longterm view is one of the most valuable aspects of ARS's 193,000-acre Jornada Experimental Range near Las Cruces, New Mexico.

The work at the New Mexico location dates back to field research initiated by the USDA in 1912 , when the Jornada Experimental Range was first established. With nearly a century of data, it is possible to see the influence of episodic events on arid rangelands. Management practices that appear to be appropriate suddenly are shown to have significantly different results when a 1 -in-50-years event like a fire or severe drought stresses the environment.

"We have about 90 years of data on a whole suite of factors," said Kris Havstad, research leader at Jornada. "Not only is this a truly long-term amount of data that you don't see very often about a single, large region, but so much of these data, especially from the early years, was very meticulously and laboriously accumulated, which gives it tremendous quality." Today, scientists at Jornada are developing new technologies to apply ecological concepts to rangeland management. "We are developing objective assessment tools that are oriented toward ecological attributes without putting any value judgement on specific activities," Havstad said.

One of the Jornada researchers' major accomplishments to that end was the 1999 publication Interpreting Indicators of Rangeland Health, a manual for assessing the ecology of an arid rangeland. The manual provides a way to develop a qualitative ecological "snapshot" that gives the land manager an initial understanding of the status of the land. ARS jointly led the effort to produce this manual together with rangeland scientists from the US Geological Survey, NRCS, and BLM. The manual is now in widespread use in the United States, and the Mexican government has just translated it into Spanish. BLM is considering adopting the manual, and it is also being considered as a way to assess rangeland for Farm Bill actions. A 4th revision is now being printed.

This year, the Jornada researchers are also publishing a monitoring manual to help range managers make quantitative measurements for a wide variety of soil conditions and vegetation. Both publications can also be found on the Internet at http://usdaars. nmsu.edu/JER/Monit_Assess/monitoring.htm.

"People will be able to make their own objective measurements and see for themselves the result of their own actions," Havstad pointed out. "I think it will lead to more management by hypothesis, where a manager can say, 'Here's what I think will happen if I do this,' and then they will have a way to objectively see if that hypothesis was correct."

Other activities at the Jornada Experimental Range include development of ecologically based technologies for remediation of degraded rangelands, animal-behavior-based strategies for livestock management, and predictive models of ecosystem responses to changes in climate and other management-dependent and -independent drivers.

But the work at Jornada is not just about that specific range. Desertification is a major threat to dry areas around the world, and Jornada studies and collaborations will help infer the causes and consequences of desertification worldwide.

Further north, in the semiarid short-grass steppes, ARS operates the High Plains Grasslands Research Station outside Cheyenne, Wyoming, and the Crops Research Laboratory on the campus of Colorado State University in Fort Collins, Colorado, where grazing lands research dates to the 1930s. Work there showed stocking rates on the northern mixedgrass prairie have a greater impact on rangeland and animal responses than rotational grazing. Research from these labs was instrumental in developing the recommended guidelines for moderate grazing

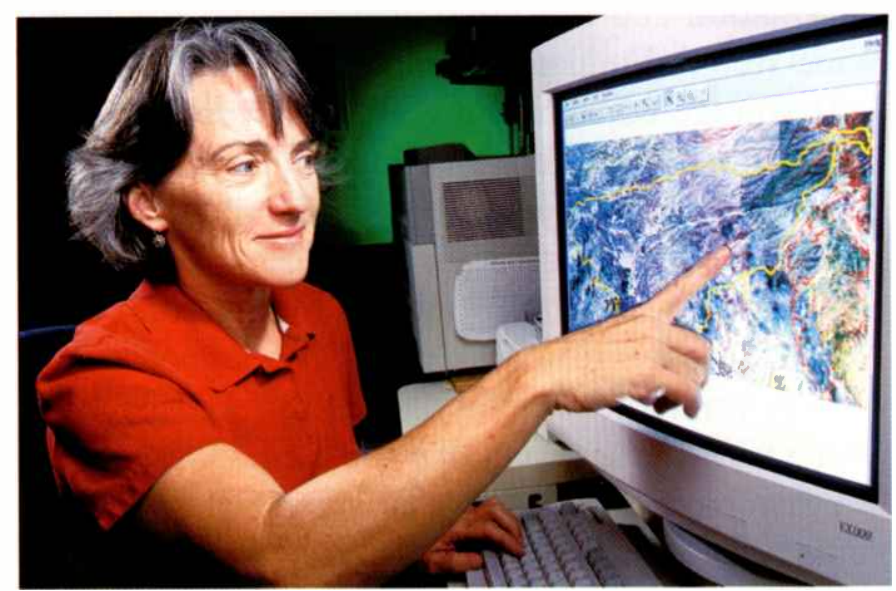

Agricultural Research Service hydrologist Susan Moran assesses the condition of grassland from an image produced by a satellite sensor. 
practices that ranchers throughout that region now commonly follow, stocking native grasslands throughout the grazing season at levels that remove $40 \%-50 \%$ of the current growth.

Building on the decades of research, the Colorado unit is now developing scientifically sound monitoring and management protocols for rangelands. The ARS researchers are also evaluating the impacts of global climate changes on rangeland ecology and the emission of greenhouse gases. They have already found that carbon and nitrogen cycles and soil carbon storage on the short-grass steppe and northern mixed-grass prairie may be manipulated through grazing management and the interseeding of legumes.

\section{Simple Objective Tools}

While some models developed by ARS are complex tools used by scientists for refining our understanding of the rangelands, many more are designed for use by the land manager to enable better decisions to be made about livestock production and the environment.

For example, at the ARS Southwest Watershed Research Center in Tucson, Arizona, researchers are working on a number of methods for monitoring, assessing, and predicting the effects of land use and management practices and changing climate patterns on soil erosion processes and watershed processes for arid rangelands.

An important tool developed at the Tucson center is the Hillslope Erosion Model (HEM). This model is easy to use, allowing land managers to "plug in" information and run the model right on the World Wide Web to simulate erosion along a hillslope.

"If you are contemplating a management decision like getting rid of the mesquite or putting in terraces on a particular hill, you can go to the model and see if it is likely to increase or decrease erosion," said Susan Moran, research leader at the Tucson center. "The Hillslope Erosion Model is also a good way to quickly prioritize which hillsides to remediate first after a high-impact event like fire comes through."

A major asset of HEM is that it simplifies the more complex erosion models researchers use, so anyone can use it to see relative differences that changes in management will make on erosion, Moran added. NRCS in Arizona is already using HEM to look at the effect of management techniques on upland sites, especially the impacts of grazing versus nongrazing in prevention of soil erosion.

Land managers face special problems when the geographic area they are trying to manage is extremely large or, in some instances, inaccessible. At the Tucson center, the ARS researchers are helping solve this problem with RANGES, a computer program that uses satellite images to produce maps of how much forage is growing on different parts of the range in specific locations. These maps could prove useful in many ways; for example, the Forest Service hopes to use them to monitor forages to determine grazing rates, and BLM is using them to determine whether various sites provide suitable habitat for bird nesting.

"We started putting this idea together because the Arizona Cattlemen's Association asked us for a tool that would give them a fact-based method to document the effect of management over large areas," explained Philip Heilman, the ARS research biologist who developed RANGES. "Since the concept has proved so useful, we hope to turn it over as a commercial product for land managing."

RANGES is a valuable tool capable of providing an objective measure of how much forage is available, which will make it easier to objectively settle questions about grazing rates, Heilman added.

\section{Environment and Livestock: Not Natural Enemies}

The northern Great Plains is a sometimes harsh but very robust environment, fully capable of supporting a wide array of uses including livestock production.

"After all, it is an environment that evolved to be grazed, whether by unmanaged wildlife like bison or by managed cattle," explained rangeland scientist Rod Heitschmidt with the ARS Fort Keogh Livestock and Range Research Laboratory in Miles City, Montana. "The challenge for us is to develop a better understanding of vegetation-environmentlivestock interactions in this region so that we develop fully sustainable rangeland management strategies that produce beef effectively."

One course of study in use at Fort Keogh is a "roof on wheels"- - a rainout shelter that lets researchers simulate different seasonal patterns of 


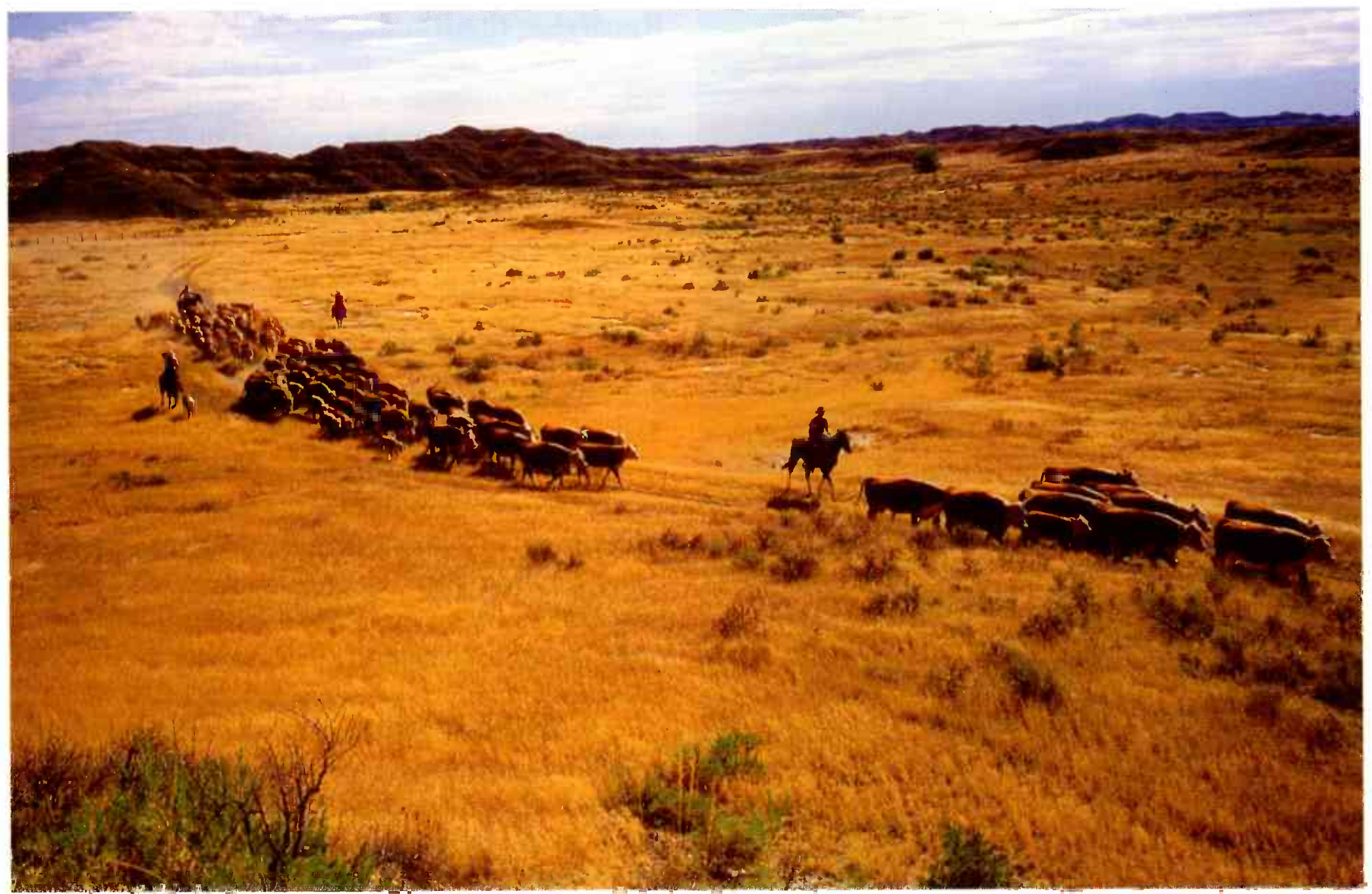

At the Agricultural Research Service's Fort Keogh Livestock and Range Research Station in southeastern Montana, one of the largest in the world of its kind, researchers help ensure a plentiful supply of meat while protecting the rangeland environment.

rainfall, including drought. Researchers are then able to evaluate the impacts of managed grazing during and after different weather patterns.

For example, researchers have found that it is not always necessary to "rest" an area for several years after a summer drought before returning it to grazing. In experiments, periodic grazing during and in the months after a summer drought had little or no negative impact on postdrought rangeland recovery rates. Now the researchers are studying the effects of grazing with a pattern of spring drought and wet summers, which they believe is much more significant in terms of the impact of immediate grazing.

The researchers' goal is to provide guidance for the timely implementation of drought management strategies. Although many producers have a drought management plan, implementation of plans is often reactive rather than proactive.

"The problem with that is that damage may be unnecessarily imposed on a piece of ground during drought that may require an extended amount of time to overcome after drought," said Heitschmidt. "The best approach is to implement proactive drought management plans that prevent any serious damage to the rangeland resource during drought, so that recovery is much quicker after drought. We want to provide early guidance that says, "If only this much rain comes in spring, this is what you need to do the rest of the year to minimize the impact of the spring drought on the overall health and vitality of both the rangeland ecosystem and the ranching business."

But ARS research goes far beyond just keeping rangeland healthy; the goal is combining sustainable land practices with good livestock production. Since Fort Keogh's earliest days as a USDA research lab in 1924, scientists there have worked on enhancing rangeland-based livestock production, particularly of cattle, through improved understanding of genetics, reproductive physiology, and nutrition and their interactions with grazing on rangeland. 


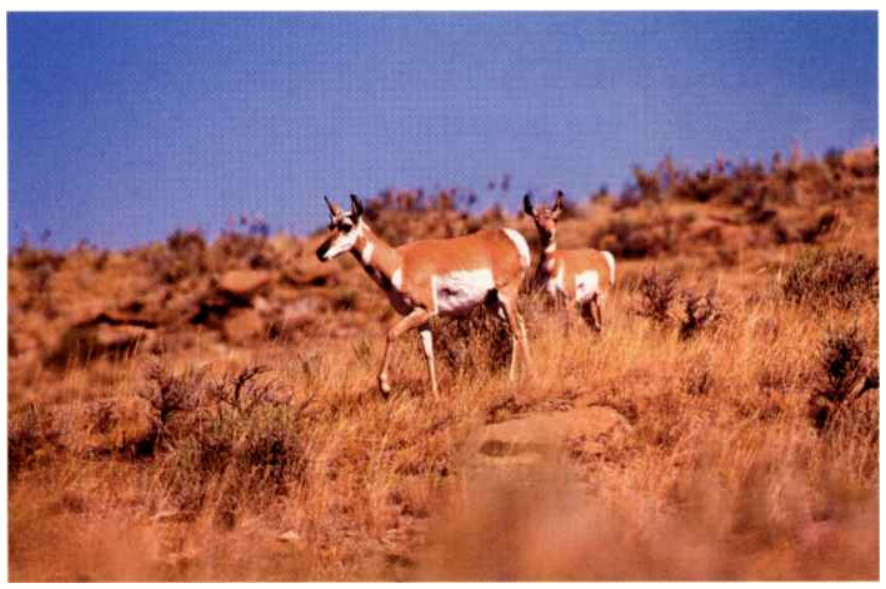

Agricultural Research Service scientists are helping users of American rangelands meet the challenge of managing multiple uses sustainably.

Free-roaming animals are a unique challenge to researchers. Diet diversity, large grazing areas, genetics, management issues, and environmental stresses all interact to influence nutrient intake and utilization. Still, such studies at Fort Keogh during the 1970s and 1980s helped devise more effective winter feed supplementation systems. There have been other improvements over the years in reproduction, nutrition, and production. Today, all parts of this location's program are closely tied to rangeland management and how varying management schemes impact the rangeland environment, with a focus on developing management schemes that benefit the environment and are fully sustainable.

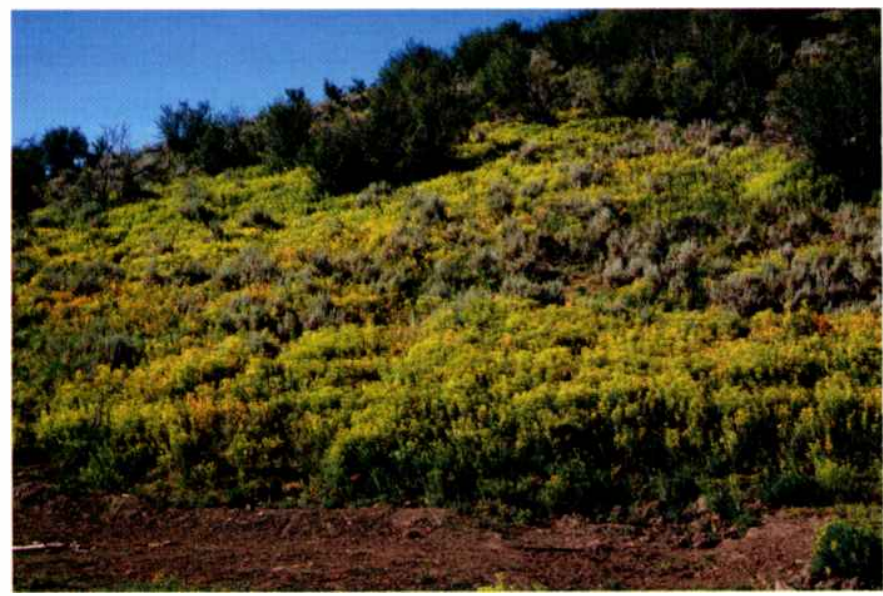

Finding economical and environmentally friendly ways to control invasive weeds like the leafy spurge taking over this hillside in Colorado is a big part of Agricultural Research Service rangeland research.

\section{Repairing the Range}

Invasive weeds have been an ongoing problem in rangeland management. They can reduce biological diversity, production, livestock grazing, and wildlife habitat.

One of ARS's most notable successes in weed management has occurred in the collaborative effort known as TEAM Leafy Spurge, which uses biological controls in an area-wide integrated pest management to control this noxious Eurasian native weed that now infests 5 million acres of land in 38 states. This was the first ARS area-wide program designed to systematically address a regional weed pest problem and successfully integrate biological controls into such a program. This approach not only increases control of the invader but also minimizes negative environmental effects sometimes associated with overuse or misuse of other, conventional tools, such as herbicides.

The foundation of this effective, affordable, and ecologically sustainable effort is a complex of techniques that includes a species-specific biocontrol agent-the leafy spurge flea beetle-along with sheep grazing, herbicides, reseeding, burning, and clipping. Between 1998 and 2002, the program reduced leafy spurge foliar cover by $80 \%-100 \%$ at most of the demonstration sites.

"Preliminary economic analysis estimates the benefits of the control program, which has distributed more than 48 million flea beetles and countless amounts of information, have already exceeded $\$ 6.7$ million in just the 4-state region of the Dakotas, Montana, and Wyoming," said Gerald L. Anderson, ARS ecologist and director of TEAM Leafy Spurge, which is headquartered at the ARS Northern Plains Agricultural Research Laboratory in Sidney, Montana.

Now that the development and demonstration of effective control methods against leafy spurge is completed, research attention is shifting to reestablishment of more desirable plant communities. Native plant seed collection is under way, with an eye to reestablishing a diverse ecology of plants after leafy spurge is driven back.

Other ARS projects are tackling a variety of invasive weeds such as yellow starthistle, pepperweed, annual brome grasses, sagebrush, western juniper, prickly pear, creosotebush, and saltcedar. 
Saltcedar, a noxious weed infesting more than 1 million acres in the western United States, invades riparian areas and produces thick, impenetrable stands that lower water tables and deplete stock ponds and small streams. ARS and other national and state agencies have come together in a Saltcedar Biological Control Consortium to develop and implement biocontrol.

Their initial success was finding the Chinese leaf beetle, Diorhabda elongata, which has been approved for release as the first insect biocontrol agent for saltcedar. Releases in northern areas, particularly in Nevada, Wyoming, Utah, and Colorado, have resulted in hundreds of acres of defoliated saltcedar after just 2 years. Four ARS locationsthe Western Regional Research Center, Albany, California; the Exotic and Invasive Weeds Research Unit, Reno, Nevada; the Grassland Soil and Water Research Laboratory, Temple, Texas; and the Northern Plains Agricultural Research Laboratory, Sidney, Montana-are involved in the effort.

Farther west in Burns, Oregon, at the Eastern Oregon Agricultural Research Center, a cooperative research effort between ARS and Oregon State University is looking at ways to restore a healthy diversity of vegetation in place of western juniper in the sagebrush steppe of the Great Basin region. For 12 years, the ARS and university researchers have evaluated plant response to juniper cutting, in cooperation with the BLM and a private landowner. They found that juniper cutting resulted in a doubling of native perennial grass production. They concluded that expensive reseeding is not needed when native bunchgrass densities are greater than 2 plants per square meter in drier-type sagebrushgrass plant communities. BLM, as well as ranchers in Oregon and Idaho, is using these results to formulate their juniper control plans.

Research at Burns also set the guidelines in the 1950s and 1960s for managing native flood meadows, the base property for most ranches in the Great Basin, from cutting heights and times to optimum water management.

Control methods for invasives such as sand sagebrush, shinnery oak, and pasture weeds that infest nearly 20 million acres in the Southern Plains have come from the Southern Plains Range Research Station in Woodward, Oklahoma. They have also

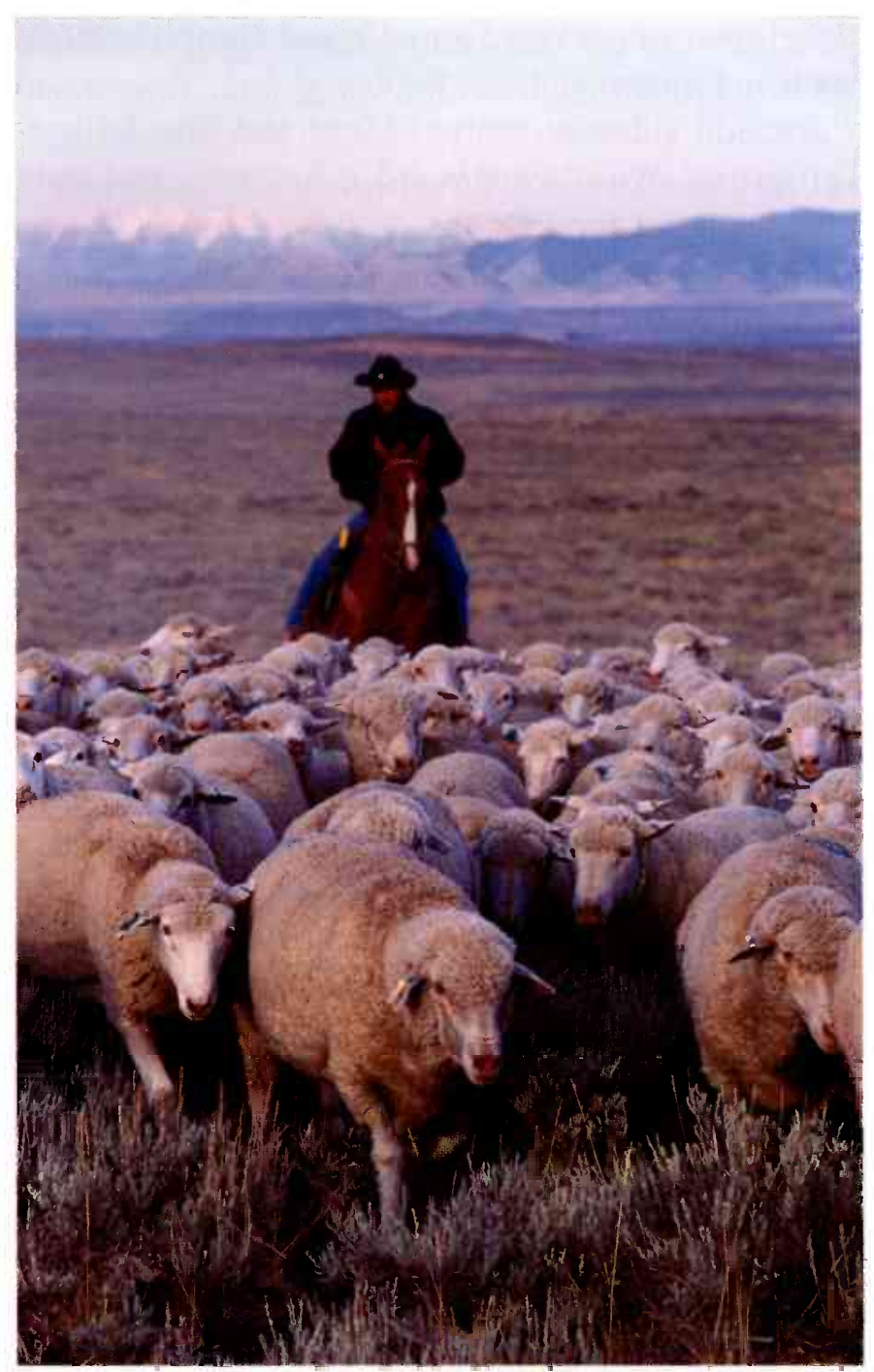

Herding sheep to research sites at the US Sheep Experiment Station near Dubois, Idaho. These sheep, with their diverse diet preferences, may help native species compete against invasive species in the sagebrush steppe.

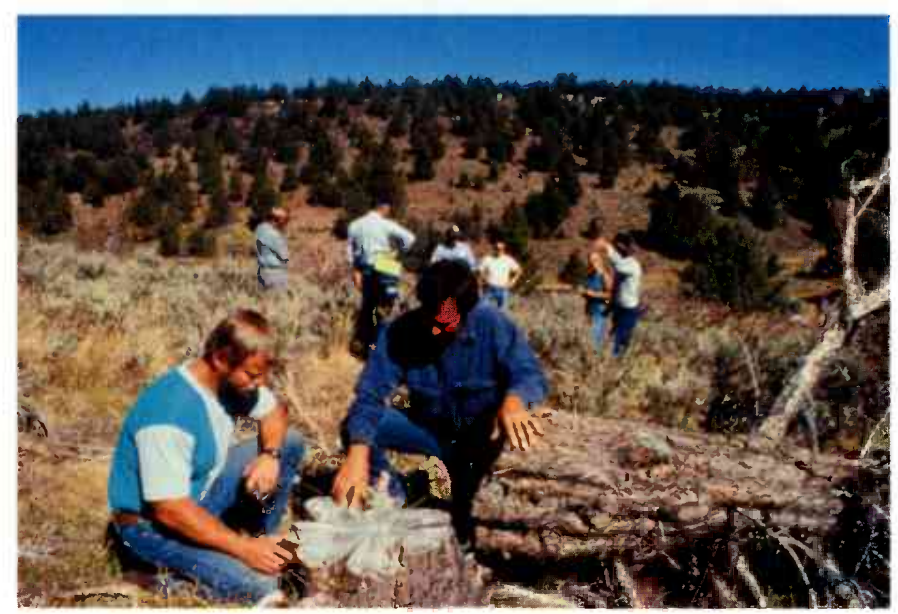

Agricultural Research Service researchers and collaborators examine juniper as they develop ways to control it. 
developed important forage grass improvements, such as Capitan and Marfa blue grama, Tucson and Coronado sideoats grama, Mesa and Texoka buffalograss, Woodward sand bluestem, and Pete Eastern gammagrass.

Developing improved varieties of both native and nonnative forages has been a significant part of ARS's laboratories. Among the native varieties released by the ARS Forage and Range Research Laboratory in Logan, Utah, are 2 globemallows, a broad-leafed native species; several Indian ricegrasses; a perennial bunchgrass ideal for restoring sandy soil rangeland with greatly improved seed germination; and P7, a bluebunch wheatgrass, released in 2001. One of the improved Indian ricegrasses, Rimrock, released in 1996 with NRCS, retains its mature seed longer than many other Indian ricegrasses, which will make seed easier to harvest and less expensive to produce.

"Seed costs are often a problem with native plants for restoration and forage plantings," said ARS plant physiologist N. Jerry Chatterton, research

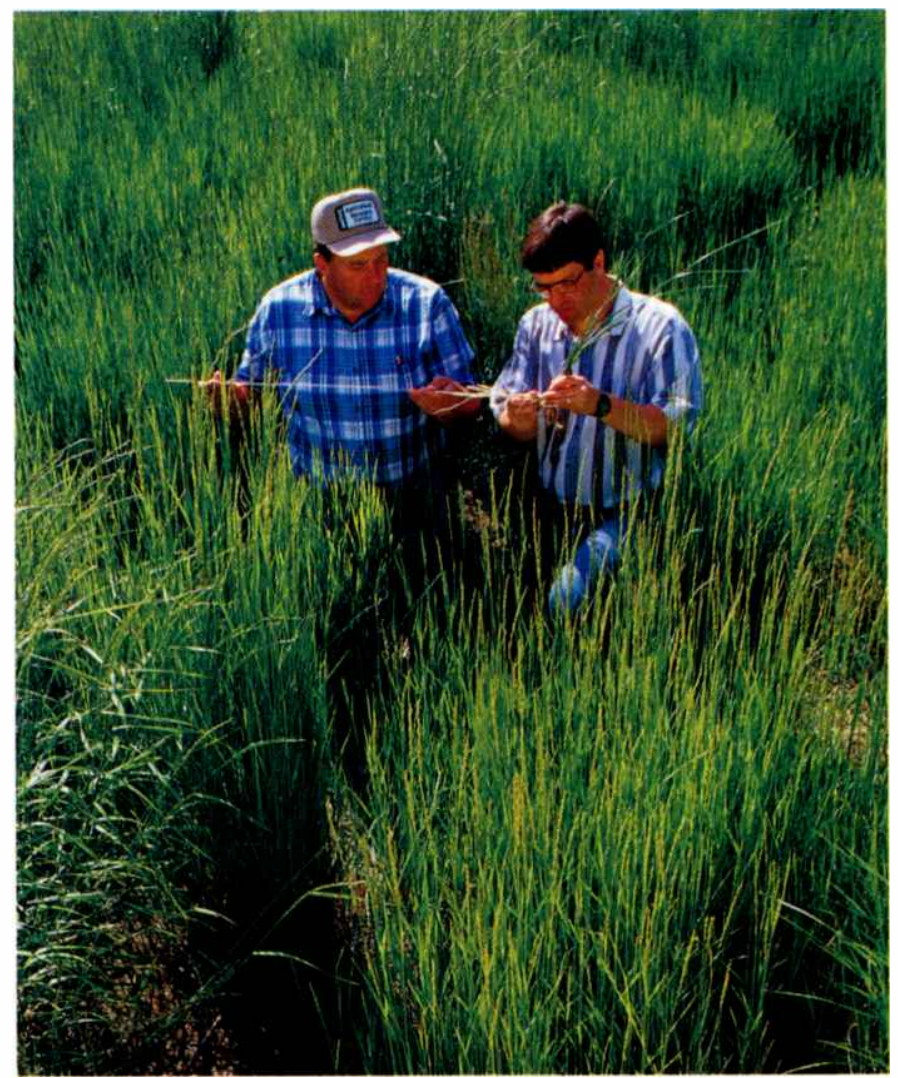

The Agricultural Research Service has developed many important forage varieties for range restoration and enhanced grazing value for livestock and wildlife. leader at the Logan lab. "It's difficult to produce enough seed from many of them at an affordable cost to use for rangeland seeding."

Another native is Sand Hollow, released in 1996, the first bottlebrush squirreltail grass released for commercial production. It withstands wildfires and germinates readily. One of Sand Hollow's primary intended uses is to restore rangelands currently overwhelmed by highly aggressive, nonnative plants, such as cheatgrass or medusahead wildrye. Sand Hollow is best suited for sandy soils throughout the Snake River region of southern Idaho as well as in parts of Oregon, Nevada, and Utah.

Other significant accomplishments from the ARS lab at Logan include development of 3 drought-tolerant grasses: Hycrest crested wheatgrass, released in 1984; Bozoisky Russian wildrye, which combines high drought tolerance and enhanced seedling vigor, released in 1985; and Vavilov Siberian crested wheatgrass, released in 1995.

"For several years, Hycrest was the most widely grown annual cool-season grass in the US, except for Kentucky bluegrass," said Chatterton. "It came out just before the first conservation reserve program and was used heavily in that program. Hycrest and Bozoisky have been used to stabilize many areas following wildfires because they have excellent seedling vigor, plus they offer good forage value."

Research is now under way to develop several dryland legumes for use on semiarid rangelands that will add nitrogen in the ecosystem.

At the ARS Wheat, Sorghum, and Forage Unit in Lincoln, Nebraska, scientists have been developing ways to improve the establishment of grasses and native legumes, including information that led to the labeling of 3 herbicides for use during planting establishment. This research reduced costs by more than $50 \%$ and saved millions of dollars in seeding costs during the establishment phase of the Conservation Reserve Program.

They also developed and released many varieties of native and introduced grasses that have been used to reseed pastures and rangelands and for conservation plantings in the central Great Plains.

The laboratories at Logan, Woodward, and Lincoln are just part of the network of ARS locations that have released dozens of important range- 
land cultivars over the years. Other locations include the Grazinglands Research Laboratory, El Reno, Oklahoma; the Forage Seed and Cereal Research Unit, Corvallis, Oregon; the Southern Plains Agriculture Research Center, College Station, Texas; and the Northern Great Plains Research Laboratory, Mandan, North Dakota.

Since the central Great Plains receives more rainfall than the more westerly rangelands, researchers at the Northern Great Plains Research Laboratory at Mandan focus on integrating rangelands livestock production with pasture and crops management to develop more sustainable farming systems. To support this effort, the lab has developed a number of cool-season forage grasses and originated the concept of using seeded pastures to complement native range. They have also done pioneering research on the use of nitrogen fertilizer and herbicides to restore depleted rangelands in the 1950s and 1960s.

Livestock illness, abortions, and death from locoweed, larkspur, broom snakeweed, ponderosa pine needles, and other poisonous plants are not the scourge they once were to the ranching community because of the work of ARS's Poisonous Plant Research Laboratory at Logan, Utah. Poisonous plant-induced birth defects result in estimated losses of over $\$ 3.4$ million annually to the livestock industry in the western United States.

The laboratory's highly interdisciplinary team of chemists, veterinarians, animal scientists, and range scientists systematically investigates problems to find effective treatments for sick animals and to develop management practices to prevent poisonings. First, they identify toxic chemicals causing the problems and then determine how the chemicals affect the animal. This information gives rise to improved diagnostic procedures and treatments. The in-depth study of the chemistry and physiological effects of the alkaloids found in the toxic plants has also resulted in identifying chemicals that show promise in treating cancer.

Once the toxic mechanisms are well understood, the scientists determine how climate, soils, plant growth, and other environmental factors affect the production of the poisonous chemicals within the plants and influence animal consumption of the plants. This information is used to develop live- stock grazing systems that keep the animals away from the plants when the plants are dangerous but to allow grazing the rest of the time.

Experiments by one ARS researcher at the Poisonous Plant Research Laboratory, for example, found that the poisons in lupines inhibit natural movements of the unborn animal in the womb, resulting in cleft palate and severe skeletal birth defects. His findings improved the management strategies that ranchers use to safely graze their animals, especially during critical gestational times. In addition, this research is of great interest to biomedical scientists investigating the causes of - and potential therapeutic intervention forcleft palate and other birth defects in humans.

\section{Water Quality}

Hand in hand with soil and vegetation preservation is the need to maintain water quality. Foragebased livestock systems in Florida's rangeland and tame pasture associations have been implicated as major contributors to deteriorating surface and groundwater quality, particularly because of phosphorus from manure. At the ARS Subtropical Agricultural Research Station in Brooksville, Florida, soil scientist Gilbert C. Sigua has been assessing the impact on soil and water quality of cattle congregation sites around mineral feeders, water troughs, and shade areas.

"While we have found higher concentrations within 5 feet of the center of cow concentration sites, these areas appear to be sinks with no special movement either vertically or horizontally," Sigua said.

Where phosphorous levels do threaten water quality, the lab is looking at ways to remediate the problem. One idea being studied at the Brooksville lab is the use of alum in conjunction with wetland treatment cells, which can enhance the treatment of storm water runoff into the Florida lakes.

"We started this project 3 years ago because cattlemen in Florida were concerned about meeting standards on total maximum daily loads. They would like better ways to handle the problem of maintaining water quality," Sigua said.

And finding a better way is what ARS is all about. 


\section{Fire on the Range}

Wildfires, prescribed burning, and the effects of postfire grazing have been the subjects of many debates among scientists and land managers. When a wildfire blazed through 500 hectares of grazing land near ARS's US Sheep Experiment Station near Dubois, Idaho, during the summer of 2000 , it provided an opportunity for research on grazing animals' impact on biodiversity recovery that has sparked a whole new round of discussion.

The 2000 fire burned through half of the land that had been in a 50-year study on the effects of grazing at different times of the year on plant biodiversity. In this study, control pastures that had not been grazed at all had been overtaken by a heavy canopy of sage brush. The fallgrazed pastures had less sagebrush and more perennial forbs, while spring-grazed pastures had more grass and sagebrush.

When the fire roared through, the ungrazed

land suffered the most: there wasn't a green plant left. The spring-grazed fared a little better; between $3 \%$ and $5 \%$ of the area was not burned. By far, the fall-grazed land suffered the least, with $15 \%-20 \%$ remaining unburned. The number of species each pasture now supports is virtually identical, but more of the spring-grazed land is taken up by invasive and annual species. Researchers are now looking at whether allowing sheep to graze relatively soon after a wildfire, instead of the 2 or 3 years of rest usually provided, could prevent takeover by invasive species.

Land managers have been increasingly using prescribed fires for control of woody invasive species and hazardous fuel reduction. Last year at the Northwest Watershed Research Center (NWRC) in Boise, Idaho, ARS scientists began evaluating the effects of 20 -year intervals of prescribed fire on soil moisture, erosion, water quality, vegetation, and grazing animal distribution. The researchers are especially interested in the impact of removing western juniper by prescribed
A prescribed fire at the Henninger Ranch of the US Sheep Experiment Station near Kilgore, Idaho, is used as part of a research project to determine how to establish native vegetation after fire in the sagebrush steppe. burning on the watershed. It will be at least a decade of monitoring the watershed before the researchers will have any solid conclusions.

To help land managers make choices about mitigating erosion following wildfires and prescribed burns, NWRC, in cooperation with the Forest Service, has also developed a Web-based Erosion Risk Management Tool (ERMiT). The program models the effects of various postfire mitigation techniques, such as contour-felled logs, straw wattles, hand trenches, straw mulch, contour raking, and wood mulch, on controlling soil erosion and to identify areas of high erosion risk. 